\title{
Pertunjukan Seni Talawengkar sebagai Atraksi Seni Budaya di Desa Sitiwinangun Kabupaten Cirebon
}

\author{
Turyati, Nani Sriwardani \\ Jurusan Seni Tari, Fakultas Seni Pertunjukan, \\ Institut Seni Budaya Indonesia (ISBI) Bandung \\ Jalan Buah Batu No 212 Bandung \\ Tlp. 081221837636, E-mail: turyati.isbi@gmail.com
}

\begin{abstract}
Pottery is a tool or device made of clay and is usually used in everyday life. Pottery is one of the works that was born from the past and still survives today. In the past, pottery was a container for storing crops, foodstuffs, and other consumables. Apart from having functional and historical value, the pottery also has aesthetic value. This pottery is the inspiration for the creation of Talawengkar performance art. Talawengker is defined as shards of pottery, from which the fragments are reused as a medium for children's play. The object of study is in Sitiwinangun because this area is a location for pottery handicrafts. This article describes the collaborative creative process in research participatory action research. The purpose of creating this artwork is an effort to empower the people of Sitiwinangun Village. The results of the research are in the form of works of art through the Talawengkar performance art attraction pattern using floor patterns and dynamic motion.
\end{abstract}

Keywords: Talawengkar Performance, Pottery, Attractions, Cultural Arts

\begin{abstract}
ABSTRAK
Gerabah merupakan alat atau perangkat yang terbuat dari tanah liat dan biasanya digunakan di kehidupan sehari-hari. Gerabah salah satu karya yang lahir dari masa lalu dan masih bertahan sampai sekarang. Di masa lampau, gerabah merupakan perabotan wadah penyimpanan hasil tanam, bahan makanan, hingga barang pakai lainnya. Selain memiliki nilai fungsi dan sejarah, gerabah juga memiliki nilai estetika. Gerabah inilah yang menjadi latar belakang inspirasi sebagai penciptaan seni pertunjukan Talawengkar. Talawengker diartikan sebagai pecahanpecahan gerabah, dari pecahan itulah yang dimanfaatkan kembali menjadi media permainan anak. Objek studi berada di Sitiwinangun, karena daerah ini merupakan lokasi kerajinan gerabah. Artikel ini memaparkan proses kreatif kolaboratif dalam penelitian participation action reseach. Tujuan penciptaan karya seni ini adalah sebagai upaya pemberdayaan masyarakat Desa Sitiwinangun. Hasil penelitian berupa karya seni melalui pola atraksi seni pertunjukan Talawengkar mengunakan pola lantai dan gerak dinamis.
\end{abstract}

Kata kunci: Pertunjukan Talawengkar, Gerabah, Atraksi, Seni Budaya

\section{PENDAHULUAN}

Indonesia memiliki aneka ragam sumber daya alam yang sangat kaya. Mulai dari pertanian, pariwisata, kekayaan laut, pertambangan, dan masih banyak lagi.
Pemanfaatan sumber daya alam dilakukan oleh manusia sebagai usaha untuk memenuhi kebutuhan hidup berupa sandang, pangan, papan, dan kebutuhan tersier lainnya. Pemanfaatan sumber daya alam juga 
membuat terbukanya kesempatan kerja bagi masyarakat desa yang jauh dari kota. Kesenian tradisi Indonesia, mulai dari musik, tarian, kuliner, bangunan, hingga kreasi seni peninggalan leluhur. Kekayaan budaya inilah yang warisan nenek moyang yang senantiasa perlu kita kembangkan hingga sekarang.

Pemanfaatan sumber daya alam dan kesenian tradisi sesungguhnya sudah ada sejak dari dulu. Salah satu implementasinya adalah gerabah. Sejak dulu kerajinan gerabah sudah ditekuni oleh masyarakat Desa Sitiwinangun. Kekayaan sumber daya alam berupa tanah liat yang ada di desa setempat tidak disia-siakan begitu saja. Tanah liat yang mudah untuk diolah kemudian diberdayakan untuk dimanfaatkan agar memiliki nilai fungsi dan nilai ekominis. Hal ini juga menjadikan tanah liat yang diproses menjadi gerabah, sebagai komoditi utama penggerak roda perekonomian di Desa Sitiwinangun. Menurut Addien (2010, hlm. 17) "gerabah merupakan perkakas yang terbuat dari tanah liat atau lempung yang dibentuk kemudian dibakar untuk dijadikan alat-alat yang berguna membantu kehidupan". Gerabah sendiri dapat berbentuk barang pakai seperti piring, mangkuk, peralatan dapur, atau cinderamata yang memiliki ciri khas tertentu seperti gantungan kunci, hiasan dinding, serta guci antik.

Gejala pada desa Sitiwinangun, pada dasarnya merupakan implementasi dari UU No. 32 Tahun 2004 tentang Otonomi Daerah, setiap daerah diberikan kebebasan dan kewenangan untuk menentukan arah pembangunan ekonominya masing-masing.
Oleh karena itu, diperlukan kemampuan daerah dalam menggali dan mengembangkan potensi-potensi yang dimiliki sebagai sumber kegiatan perekonomian(Desi ariayanti 2016, hlm. 348). Tradisi Desa Sitiwinangun memiliki kelekatan dengan masyarakatnya kemudian dikreasikan untuk memperoleh manfaat bagi tercapainya kemakmuran hidup masyarakatnya. Mulai dari musik, tarian, kuliner, bangunan, hingga kreasi seni peninggalan leluhur. Kekayaan budaya inilah yang menjadi warisan nenek moyang yang senantiasa perlu dikembangkan hingga sekarang. Hal ini relevan dengan paparan Hari Poerwanto "Bahwa manusia dan kebudayaan merupakan kesatuan yang tidak terpisahkan, sementara itu pendukung kebudayaan mahkluk manusia itu sendiri. Sekalipun makhluk manusia akan mati, tetapi kebudayaan yang dimilikinya akan diwariskan pada keturunannya, demikian seterusnya" (2000, hlm. 50).

Barang-barang yang hadir di pasaran saat ini umumnya didominasi oleh bahan instan dengan bahan plastik, hal ini berdampak juga pada harga jual yang lebih murah. Faktor inilah yang semakin hari membuat gerabah tersisihkan dari kebutuhan masyarakat. Gerabah juga identik dengan barang bernilai sejarah yang dilihat dari proses, bentuk, bahan, dan sebagainya. Dibandingkan dengan barang-barang modern yang biasanya terbuat dari plastik, gerabah memang memiliki kerumitan sendiri dalam pembuatannya. Proses pembuatannya membutuhkan waktu yang cukuplama, karena pembuatannya secara manual. Tanah liat dibentuk menggunakan 
laker hingga menjadi bentuk gerabah yang diinginkan. Proses pengeringannya pun masih traidisional, yaitu menggunakan tobong atau tempat pembakaran gerabah. Barulah setelah itu gerabah dicat atau dihias sesuai dengan yang diinginkan. Gerabah dengan segala proses produksinya dikemas sebagai objek daya tarik wisata belanja. Gerabah tidak lagi hanya diproduksi sebagai benda pakai, tetapi akhirnya juga diarahkan sebagai benda seni. Gerabah menjadi suvenir melalui proses produksi dengan teknik dan pendekatan yang berakar pada kepentingan wisata. Gerabah diproduksi dalam ukuran mini, menjadi gantungan kunci, penghias meja kerja, sebagai kelengkapan instalasi. Soedarsono mengkaji bahwa seni dan wisata dapat dipraktikan dengan sempurna dengan didasarkan pada teori seni wisata. Sinergitas antara seni dan wisata. Gejala yang umum dapat diamati adalah adanya bentuk-bentuk tiruan dari aslinya, singkat, padat atau bentuk mini dari aslinya; variatif dan penuh variasi, ditanggalkan nilai-nilai sakral, magis, serta simbolisnya dan relatif memiliki nilai jual yang bersaing atau murah (1999, hlm. 3).

Desa Sitiwinangun berlokasikan di Kecamatan Jamblang, Kabupaten Cirebon, Jawa Barat. Desa ini merupakan desa pengrajin gerabah. Pada tahun 2016 Desa Sitiwinangun mencanangkan diri sebagai Desa Wisata. Memiliki identitas diri sebagai 'desa penghasil gerabah', menjadikan desa tersebut memiliki kekhasan tersendiri dibandingkan desa-desa wisata lainnya. Daya saing pada produk industri masal ini tak menjadikan pengrajin gerabah Desa Sitiwinangun berhenti berkarya.
Warisan budaya gerabah Desa Sitiwinangun tetap dilakoni sebagai mata pencarian dan salah satu cara mereka untuk mempertahankan keberadaannya. Tanah liat untuk pembuatan gerabah di Desa Sitiwinangun ini bersumber dari daerah setempat dan memiliki kualitas baik. Hal ini juga yang menjadi alasan mereka tetap bertahan melestarikan kerajinan gerabah.

Pemerintah Indonesia dalam Buku Pengembangan Ekonomi Kreatif Indonesia 2025: Rencana Pengembangan Ekonomi KreatifIndonesia 2009-2015 (Depdag RI, 2008) pada bagian dua yaitu kerangka kerja pengembangan Ekraf Indonesia menggunakan model triple helix yang melibatkan peran cendekiawan, bisnis, dan pemerintah sebagai faktor utama dan faktor penggerak. Wajar apabila konteks industri kreatif memandang bahwa industri pariwisata terdapat keterjalinan antara industri kreatif dan industri pariwisata budaya lokal. Jalinan ini merefleksikan relasi kolaboratif industri pariwisata budaya dan budaya lokal dalam social balivogenic akan terbangun jejaring yang dapat mensinergikan dan saling menumbuhsuburkan antara sektor industri pariwisata budaya dan sektor industri kreatif (I Made Darmada, 2016, hlm. 786). Hal ini menjadi benih awal lahirnya komodifikasi terhadap seni budaya lokal. Hampir seluruh kesenian tradisional di Indonesia tidak terhindar dari derap komodivikasi arus ekonomi global yang dicitrakan pada industri pariwisata selalu menuntut kehadiran turisme dan pariwisata (Putra, 2008, hlm. 9).

Akan tetapi sebagai desa wisata, Desa Sitiwinangun belum memiliki pertunjukan seni sendiri khas desa setempat. Hal inilah yang 
dijadikan landasan utama untuk membuat seni pertunjukan yang masih kuat ikatannya dengan identitas Desa Sitiwinangun sebagai penghasil gerabah. Desa ini sebenarnya sudah memiliki sanggar seni yang dikelola oleh masyarakat desa, yaitu Sanggar Seni Tari “Genta Pertiwi”. Sanggar yang dikelola oleh desa ini bersifat gratis sehingga siswasiswanya tidak perlu membayar untuk belajar di sini. Mayoritas siswanya merupakan anak-anak usia sekolah dasar hingga sekolah menengah atas. Mereka berlatih satu kali dalam seminggu, yaitu hari Minggu untuk mengisi sela-sela waktu libur sekolah. Materi tari dalam sanggar ini khusus Tari Topeng gaya Slangit.

Pelatih atau guru yang mengajari siswasiswa di Sanggar Seni Genta Pertiwi masih keturunan maestro dalang topeng. Beliau merupakan cucu Bapak Jaya, yaitu kaka kandung Dalang Keni yang berasal dari Desa Slangit. Pelatih sanggar juga digaji secara rutin oleh kas yang dikelola desa.

Setelah mengenal banyak mengenai Desa Sitiwinangun, dapat terlihat bahwa desa ini cukup maju dan memiliki banyak sekali potensi apabila dibandingkan dengan desadesa lain di Kecamatan Jamblang. Alasan inilah yang menjadikan Desa Sitiwinangun menjadi salah satu model desa wisata yang berbasis atraksi seni pertunjukan.

Dalam proses perjalannya, dibutuhkan berbagai program pendampingan kepada masyarakat untuk dapat menciptakan seni pertunjukan. Seni pertunjukan ini diharapkan bisa menjadi 'wajah' yang dapat ditampilkan kepada para wisatawan atau masyarakat luar, agar lebih mengenal Desa Sitiwinangun sebagai desa pengrajin gerabah. Tujuan dari penelitian ini adalah pembuatan model atraksi seni di Desa Sitiwinangun. Pembuatan model ini merupakan upaya pemberdayaan masyarakat dari seni gerak pertunjukan berkonsep gerabah khas Desa Sitiwinangun, sehingga Desa tersebut memiliki paket wisata lokal khas Sitiwinangun.

Urgensi dari penelitian ini adalah diperlukannya pengembangan dari kekayaan potensi lokal yang ada di Desa Sitiwinangun. Adanya aktivitas para pengrajin gerabah adalah cikal bakal inspirasi karya ini untuk meningkatkansumberdayamanusiadalamseni tari. Proses ini diharapkan oleh kami sebagai seniman dan peneliti, dapat meningkatkan daya tarik wisatawan dan nilai tambah Desa Sitiwinangun sebagai desa wisata. Atas dasar pemikiran tersebut, penelitian karya tentang model seni pertunjukan Talawengkar signifikan dilakukan sebagai bentuk pertunjukan tari dalam bentuk atraksi yang dapat menghibur pengunjung atau wisatawan. Sebagaimana diungkapkan oleh Herdiani (2013, hlm. 215), bahwa rumusan tujuan dalam suatu penelitian penting untuk dilaksanakan terutama dalam pemberdayaan masyarakat dan potensinya dalam aktivitas seni budaya yang bertujuan untuk mengokohkan integrasi bangsa dan apresiasi terhadap seni budaya lokal.

\section{METODE}

Penelitian dilakukan dengan model penelitian participatin action reaseach, peneliti terlibat bersama-sama dengan masyarakat 
membuat produk yang diinginkan oleh masyarakat. Berdasarkan hal tersebut, peneliti secara bersama-sama mengeksplorasi gerabah sebagai inspirasi bentuk seni pertunjukan (Afandi, 2013, hlm. 41-42).

Bentuk kolaboratif memberikan nuansa keberagaman kearifan lokal yang dimiliki dalam satu daerah dalam konteks pertunjukanya. Ini bagian strategis melibatkan masyarakat untuk mengkreasi budaya lokal yang dimilikinya (Afrianto, 2020, hlm. 124).

Talawengkar sebagai atraksi seni menggambarkan aktivitas para perajin gerabah. Pertunjukan seni ini merupakan bentuk pengembangan dari aktivitas perajin gerabah yang ada di Desa Sitiwinangun.

Model penciptaan seni pertunjukan ini menggunakan metode kreativitas. Mengutamakan pemikiran imajinatif yang berhubungan dengan perasaan, penghayatan, khayalan, dan akhirnya menemukan sesuatu yang berarti juga bermakna agar mampu mengubah dari yang biasa menjadi luar biasa, terutama bagi masyarakat pendukungnya. Metode ini merujuk kepada Pemikiran Hawkins, yaitu:

"Kreativitas tidak dihasilkan oleh adanya peniruan, persesuaian, atau pencocokan terhadap pola-pola yang telah dibuat sebelumnya. Kreativitas menyangkut pemikiran imajinatif: merasakan, menghayati, mengkhayalkan, dan menemukan kebenaran." (Hawkins, 2003, hlm. 3). adalah:

Beberapa tahapan yang dilakukan

1. Pengumpulan Data

Pengumpulan data yang dilakukan adalah teknik wawancara dan juga observasi lapangan. Hal ini perlu dilakukan agar peneliti mendapatkan data langsung dari sumber yang kredibel. Tujuannya adalah untuk mengidentifikasi potensi yang ada di Desa Sitiwinangun.

\section{Pembuatan Konsep}

Pembuatan konsep yang dimaksud adalah konsep untuk garapan Model Atraksi Seni Pertunjukan Talawengkar. Konsep garap ini mengambil inspirasi dari kehidupan para perajin di Desa Sitiwinangun, Kabupaten Cirebon.

\section{Eksplorasi Gerak}

Eksplorasi gerak yang dilakukan untuk Atraksi Seni Pertunjukan Talawengkar dipadukan dengan seni pertunjukan setempat, yaitu Tari Cirebonan. Selain menjadi referensi, hal ini dilakukan agar Seni Pertunjukan Talawengkar tetap mengakar kepada kebudayaan yang ada di daerah tersebut.

\section{HASIL DAN PEMBAHASAN}

Dorongan untuk mengembangkan lingkungan menjadi objek daya tarik wisata, masyarakat desa secara kreatif mengelola dirinya dan lingkungannya agar menuju kepantasannya sebagai objek wisata. Proses kreatif yang demikian merupakan bagian penting dalam mencapai tujuan kewisataan. Dedi Supriadi (1994, hlm. 126) menyatakan "Selama menempuh ikhtiar kreatif, individu mendapatkan dukungan dari lingkungan sehingga ia merasa aman dalam berkreasi".

Dipaparkan oleh Piirto bahwa Ekonomi pada era globalisasi adalah ekonomi berkelanjutan/ekonomi kreatif yang berbasis 
pada pengetahuan. Berkaitan dengan peranan pendidikan dalam pembangunan berkelanjutan, paling tidak paradigmanya ada pada paradigma fungsional, yaitu berpengetahuan, berkemampuan, dan bersikap masa depan. Oleh karena itu, abad ke 21 merupakan abad kreativitas (2011, hlm. 1).

Merujuk pada definisi bahwa kreativitas adalah proses yang dihasilkan dari interaksi antara tiga kekuatan yaitu (1) budaya memiliki literatur tentang ideide, nilai-nilai (2) sistem sosial, perilaku, nilai-nilai dan informasi (meme) yang akan dilestarikan; (3) individu, sebagai unit yang membawa transformasi ke dalam domain sosial dan budaya (Eko Susanto 2017, hlm. 193).

\section{Pertunjukan Talawengker dikemas sebagai} salah satu atraksi wisata mendapat dukungan yang baik dari berbagai potensi lingkungan, sehingga dapat membangun komunikasi sosial budaya dalam konteks masyarakat lingkungan dan pengunjung wisata. Terdapat pesan ideologis tentang identitas budaya lokal dalam sajian estetika pertunjukan.

Berdasarkan penjelasan tersebut, dapat diketahui bahwa pertunjukan berfungsi sebagai sarana komunikasi untuk memberi pesan atau dalam hal ini memperkenalkan kebudayaan yang ada. Bentukseni pertunjukan sendiri ada banyak sekali, misalnya: seni tari, seni teater, seni karawitan, dan masih banyak lagi. Kesenian khas daerah biasanya berawal dari kebiasaan yang sudah melekat pada penduduk suatu daerah.

Pada setiap wilayah budaya tentunya memiliki ragam permainan yang unik dan menarik. Ragam permainan ini dapat dijadikan sebuah kemasan atraksi budaya dalam konteks pengembangan sebuah pemajuan kebudayaan daerah atau desa. Hal ini dilakukan salah satunya di Desa Sitiwinangun yang mana masyarakatnya memiliki keterampilan dan berpencaharian sebagai perajin gerabah yaitu membuat peralatan rumah tangga seperti; gentong, mangkok, gelas, piring, serta ada juga berupa hiasan-hiasan yang bisa dijadikan sebagai cinderamata para pengunjung yang datang untuk sekedar membeli oleh-oleh. Gerabah yang sudah menjadi identitas Desa Sitiwinangun kemudian dijadikan landasan dasar pembuatan seni pertunjukan.

Istilah Talawengker sendiri adalah gerabah yang terpecah-pecah. Walaupun sudah hancur dan sudah tidak terpakai lagi untuk peralatan, Talawengkar tetap bisa menjadi kepingan benda yang bisa dimanfaatkan kembali untuk permainan anak-anak di Desa Sitiwinangun. Menurut Sutrisno (Wawancara, 20 Agustus 2020) "Talawengkar tuh kalau menurut kami di sini pecahan-pecahan dari gerabah itu bu, main kami orang desa waktu kecil". Talawengkar tersebut kemudian menjadi sebuah benda yang digunakan dalam permainan anak-anak setempat. Hingga saat ini, Talawengkar masih sering dimanfaatkan sebagai permainan tradisional yang biasanya dilakukan pada sore hari, ketika anak-anak berkumpul. Kelanjutan dari wawancara dan penjelasan Talawengkar itulah yang menjadi ide lanjutan pembuatan seni pertunjukan sebagai atraksi wisata.

Desa Sitiwinangun memiliki potensi yang cukup menarik untuk dijadikan sebagai desa wisata dengan memanfaatkan masyarakatnya sebagai pengrajin gerabah. Gerabah selain untuk digunakan sebagai alat rumah tangga 
bisa juga limbahnya yang sudah tidak terpakai atau pecahan-pecahan gerabah bisa dimanfaatkan untuk bermain anak-anak seperti permainan Janepoan, engklekan dll. Permainan tersebut biasanya dilakukan sore hari menjelang malam di waktu bermain setelah anak-anak belajar mengaji.

Setelah mendapat dasar-dasar ide sebagai modal pembuatan Atraksi Seni Talawengkar, penulis kemudian menempuh tahap eksplorasi. Seperti halnya dalam Metode TaTuPa (Tabuh Tubuh Padusi) dalam sebuah karya seni tari, sebelum komposisi terbentuk menjadi satu kesatuan yang utuh, seorang koreografer atau penata tari melakukan beberapa tahap-tahap penting dalam proses penggarapannya, di antaranya melalui tahap eksplorasi, tahap improvisasi, dan tahap komposisi (Rustiyanti, 2019, hlm. 164).

Eksplorasi ini dilakukan untuk menemukan gerakan-gerakan tari yang nantinya akan mengisi Atraksi Seni Talawengkar.

Tahapan ini dilakukan berdasarkan konsep yang dipaparkan oleh Putri Rahmawati sebagai berikut,

Hal yang pertama dilakukan ialah pencarian ide, selanjutnya tahap penemuan gerak, yaitu tahap eksplorasi, tahap improvisasi dan tahap komposisi. Di samping tahap-tahap yang dilakukan, faktor-faktor pendukung lainnya ikut memengaruhi terbentuknya karya tari. Sehingga terbentuk sebuah karya yang utuh. (2019, hlm. 319).

\section{Struktur Sajian Talawengker}

Dari tahapan-tahapan yang sudah dilalui dalam proses penciptaan, maka terbentuklah
Atraksi Seni Talawengkar yang utuh. Artikel ini memaparkan secara rinci struktur sajian atraksi Talawengkar dalam Adegan-adegan sebagai berikut:

Adegan 1:

Dua penari masuk dari kanan dan kiri menarikan tari topeng berkarakter gagah dengan salah satu penari membawa sebuah gerabah yang diperebutkan hingga akhirnya jatuh dan hancur dan kemudian menjadi pecahan gerabah yang disebut Talawengkar. Talawengkar tersebut kemudian menjadi sebuah benda yang digunakan dalam permainan anak-anak. Permainan tersebut yang sering dimainkan oleh anak-anak pedesaan. Struktur koreografi yang disusun adalah sebagai berikut;

\section{Dukungan Organisasi Swasta}

\section{Adegan 1 Intro:}

a. Dua orang penari masuk dari sudut kanan kiri belakang. Memulai permainan engklekan yang menggunakan pecahan gerabah (Talawengkar)

b. Masuk satu penari dari sudut kanan belakang yang memanggil tiga penari lainnya untuk bermain Bekel (Beklen).

c. Empat penari masuk dari kanan kiri panggung memainkan permainan lompat tali.

d. Satu penari mengajak semua penari untuk main jenepo'a, dimulai dengan menyanyikan syair "Hompimpa alaium gambreng, mak ijah pakai baju rombeng, kaleng bekas gombrang gambreng!". Siapa yang kalah harus jaga lalu harus menyusun pecahan gerabah (Talawengkar) 


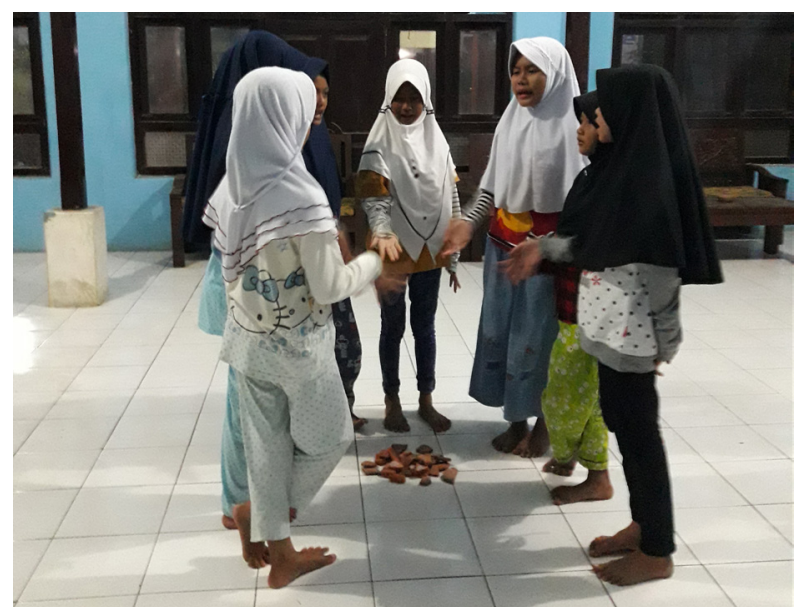

Gambar 1. Permainan Janepo'an.

Sumber: Dokumentasi Turyati, 2019

secara bertumpuk selama yang lain bersembunyi. Setelah selesai penari yang jaga mengatakan "Cem!", apabila penari ada yang terlihat atau ditemukan yang jaga harus mengatakan nama lalu mengatakan "Jenepo'an!". Suasana hikmat/ agung yang menggambarkan masyarakat agamis.

\section{Adegan 2:}

a. Satu persatu penari masuk dengan membawa alat musik gerabah dan membunyikannya dengan cara memukul bagian atas gerabah secara perlahan.

b. Sembilan penari menggerakan beberapa gerakan topeng gaya Slangit yang dipadukan dengan alat musik hingga membuat pola lingkaran.

c. Dua penari berada di tengah dikelilingi oleh delapan penari sambil menggerakan gerakan ngelarap ke beberapa sudut.

d. Semua penari perlahan duduk dengan menggerakkan gerak sembah yang bertujuan untuk memohon kepada Tuhan semoga dilancarkan dalam segala urusan pekerjaannya. f. Dua penari berdiri dengan melakukan gerakan satu putaran penuh dengan gerakan memutar perlahan dengan kedua tangan di atas kepala sambil menggetarkan sampur.

\section{Adegan 3:}

Pada adegan 3, digambarkan suasana masyarakat yang membuat gerabah (anjun).

a. Sembilan penari bergerak bersamaan dengan melakukan gerak mincid di tempat, kemudian berputar ke kanan dan ke kiri.

b. Sembilan penari bergerak ke sudut kiri depan dengan melakukan gerakan dinamis yang sama, seperti mengangkat properti ke kanan dan ke kiri menghadap ke arah sudut kanan.

c. Menggerakan gerakan canon (berlawanan) naik turun dimulai di hitungan pertama semua setengah turun lalu hitungan keempat dua penari naik lalu turun, hitungan ke lima dua penari naik lalu turun, hitungan ke enam dua penari naik lalu turun, hitungan ke tujuh dua penari naik dan hitungan ke delapan semua naik dilakukan secara berkesinambungan

d. Menghentakkan kaki dengan posisi gerabah disimpan di pundak pada hitungan ke empat menggerakan tangan ke atas dan ke bawah. Lalu berputar di tempat sampai menghadap ke sudut belakang.

e. Berpencar air mancur dengan gerakan yang sama seperti pola " $\mathrm{D}$ " sehingga membuat posisi satu penari berada di tengah dan delapan penari lainnya 


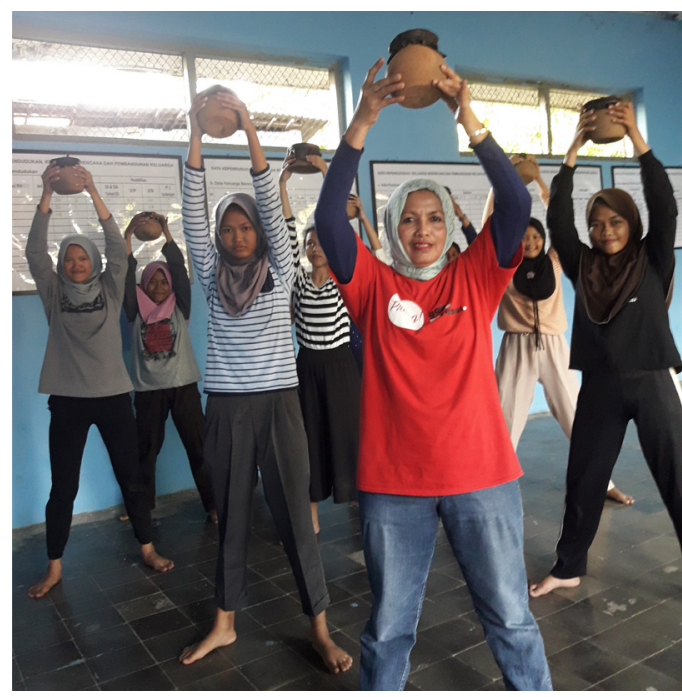

Gambar 2. Gerakan Permainan Gerabah. Sumber: Dokumentasi Turyati, 2019

berbaris di kanan depan dan di kiri belakang. Di sini menggerakan gerakan yang menggambarkan proses pembuatan gerabah.

\section{Adegan 4:}

Pada adegan ini menggambarkan suasana Desa Witinangun yang bersuka ria setelah selesai bekerja

a. Anak-anak dibagi menjadi dua kelompok masuk dengan gerakan mincid dengan memegang gerabah di pinggang sebelah kiri. Masuk dari sudut kanan belakang dan sudut kiri depan.

Sembilan penari yang duduk di bawah setelah dilewati anak-anak mereka mengikuti gerakan mincid tersebut hingga membuat dua pola lingkaran dengan arah yang berbeda.

b. Di pola lingkaran semua penari melakukan cross ke luar masuk, hingga anak-anak membuat pola segitiga dan di tengah membuat pola lingkaran dengan menggerakkan gerabah ke arah depanbelakang dan kanan-kiri, satu anak naik di

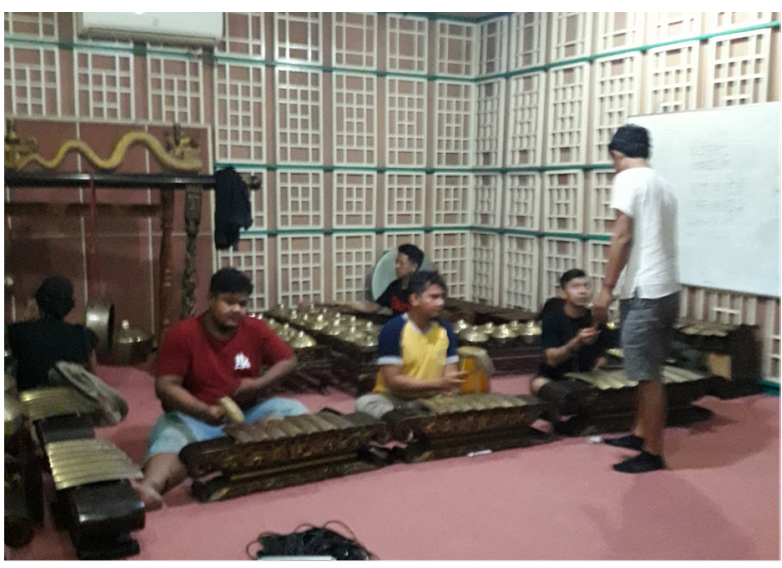

Gambar 3 Proses rekaman iringan musik Sumber: Dokumentasi Turyati, 2019

tengah dengan mengangkat satu gerabah. Setelah selesai membuat pembendaharaan gerak Atraksi Seni Talawengkar, disusunlah iringan musik yang nantinya akan mengiringi tarian tersebut. Musik merupakan medium bantu tari yang tidak kalah penting dengan medium bantu lainnya, yaitu selain rias dan busana. Iringan Atraksi Seni Pertunjukan Talawengkar menggunakan kolaborasi dari musik tradisional (gamelan) dan juga yang diambil daribunyigerabah.Musiksecaralive kemudian direkam agar selanjutnya pertunjukan Atraksi Seni Pertunjukan Talawengkar sebagai bentuk aset digital yang dimiliki Desa Sitiwinangun.

Musik iringan Atraksi Seni Pertunjukan Talawengkar memadukan musik tradisional dengan musik yang dihasilkan dari bunyibunyian gerabah atau pukulan-pukulan gerabah ketika masa proses pembuatan gerabah dilakukan. Seperti misalnya bunyi Talawengkar ketika disebarkan di atas keramik sehingga menimbulkan suara gemerincing atau pukulan-pululan dari kayu yang biasanya dijadikan alat untuk menghaluskan gerabah, ketika proses penghalusan gerabah sedang 


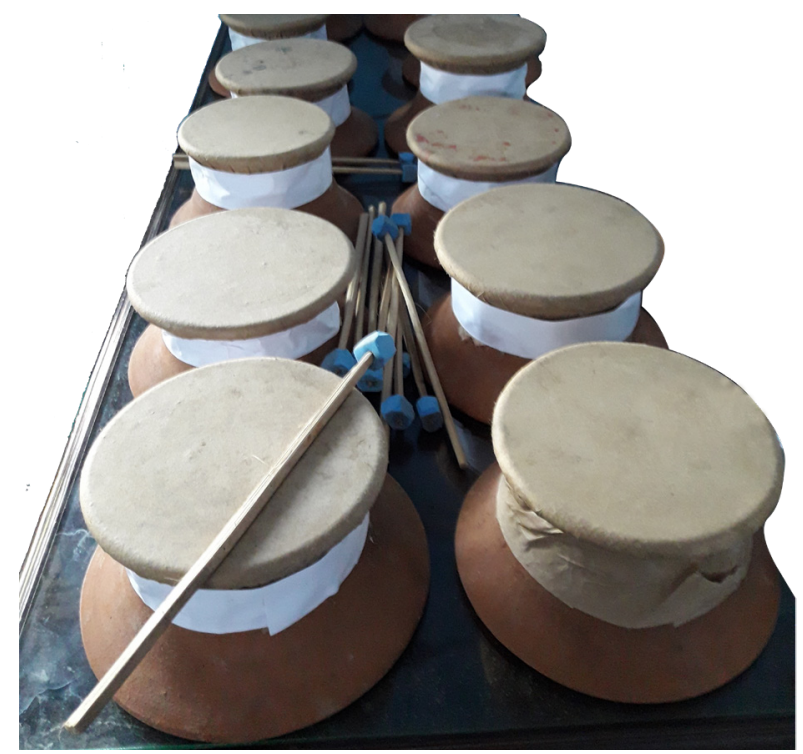

Gambar 4. Alat Musik Gerabah. Sumber: Dokumentasi Turyati, 2020

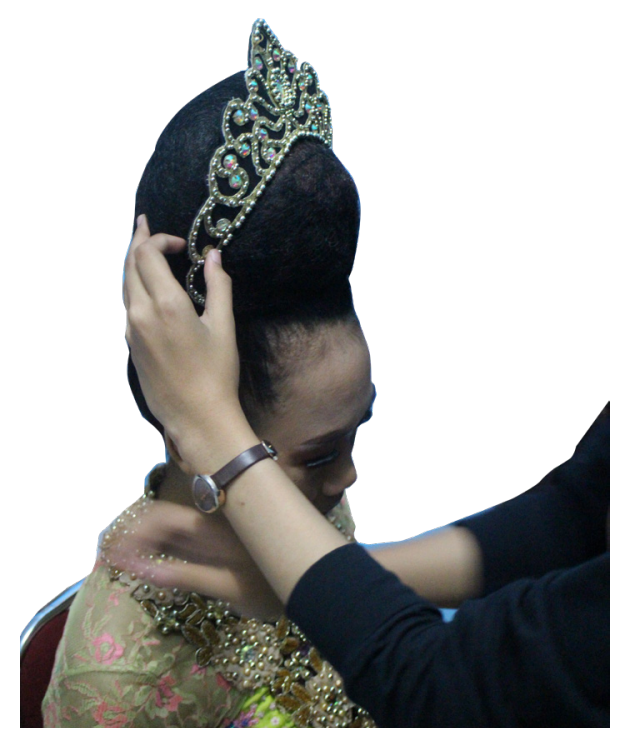

Gambar 5. Tata Rias Penari. Sumber: Dokumentasi Turyati, 2020 dibuat. Semua itu bisa dimanfaatka menjadi medium bantu alat musik pengiring tari.

Selanjutnya adalah tata rias yang menjadi medium bantu lainnya. Rias menggunakan rias panggung yang bertujuan untuk mempercantik penampilan penari sehingga penonton atau pengunjung bisa terhibur dan puas dengan penampilan pertunjukan tari.

Busana tari disesuaikan dengan tema dan gerak yang mengambil gerak pokok dari Tari Topeng di mana sanggar ini awalnya berlatar belakang dari Tari Topeng gaya Selangit sehingga kostum atau busana mengambil motif dari tari tersebut yang akan dimodifikasi sesuai kebutuhan konsep Tari, sehingga memiliki ciri khas dalam penampilannya.

\section{Pengembangan Potensi: Resistensi Nilai Ideologi dan Ekonomi}

Dalam konteks ekowisata, Talawengkar merupakan sebuah produk industri kreatif yang mencoba memperkaya nilai ideologi dengan menumbuhkan nilai ekonomi. Semua asetalam, budaya dimaknaisebagai komoditas, dan dikembangkan agar dapat memberikan tambahan yang signifikan bagi pertumbuhan kesejahteraan sosial masyarakat.

Sebagai sajian seni wisata Talawengker memenuhi kaidah sajian seni wisata yang dapat menarik wisatawan, glamour, memiliki sex appeal yang menggambarkan keunikan budaya lokal yang diusungnya. Maka sebagai industri kreatif taliwengker didukung oleh kesadaran para pelaku yang mengemasnya sebagai sajian seni wisata. Perlu disadari bersama industri kreatif diharapakan mampu menjadi rangsang bagi pertumbuhan ekonomi, sehingga dapat mencerminkan hubungan ekonomi dan budaya. Pada akhirnya, produksi komoditas akan terikat oleh eksperimen artistik dan dapat menjadi benih ketegangan laten antara seni dan pertimbangan komersial (Bahren 2014, hlm. 152).

Resistensi setiap produk wisata selalu menuntun timbulnya konsekuensi logis perdebatan dan atau peleburan dua 
kepentingan yang bersifat komersial dan ideologi. Maka sebagai industri seni budaya, hanya bisa bertahan hidup jangka panjang melalui diferensiasi produk konstan dan inovasi, sehingga harus ditemukan cara untuk melindungi pekerja kreatif setidaknya dari tekanan pasar langsung untuk selalu mendapatkan ide-ide dan inovasi-inovasi baru (Bahren 2014, hlm.153).

Hal tersebut diharapkan dapat menumbuhkan kiat suskses bagi masyarakat Sitiwinangun. Menurut Soedarsono bahwa Bali adalah adalah wilayah Indonesia yang mempelopori dalam menanggapi hadirnya pariwisata dengan kesenian (1999, hlm. 8).

Talawengkar akan dihadapkan pada tantangan keberlanjutan dan aspek kemanfaatan ekonomi dan ideologis masyarakat. Unsur indegenious culture menjadi faktor penengara idetitas kelompok masyarakat. Identitas etnis menjadi lebih penting, identitas etnis terakumulasi unsurunsur perekat atau pengikat kekeluargaan seperti unsur ras itu sendiri, kepercayaan atau agama, budaya, dan warisan-warisan para leluhurnya (Abdillah, 2002, hlm. 82).

Damar Tri Afrianto menjelaskan bahwa peran seni sangat srategis dalam upaya pengembangan pariwisata terutama untuk menarik kunjungan wisatawan. Seni dalam konteks pariwisata harus memiliki kekuatan bentuk sajian, tema serta nilai. Tema dan nilainilai yang diangkat dalam sajian seni dalam konteks pariwisata tentunya berakar dari kearifan lokal kebudayaan (2020, hlm.125).

Relasi Talawengkar sebagai seni pertunjukan harus mampu menjawab tantangan komunikasi dalam menyamaikan pesan-pesan ideologis. Sal Murgiyanto dalam Pertunjukan Budaya dan Akal Sehat (2016, hlm. 20) Pertunjukan adalah sebuah komunikasi di mana satu orang atau lebih pengirim pesan merasa bertanggungjawab kepada seseorang atau lebih penerima pesan dan kepada sebuah tradisi yang mereka pahami bersama melalui seperangkat tingkah laku yang khas (a subset of behavior).

Dari sisi pandang ekonomi, dampak komersial dari sajian Talawengkar dapat menghasilkan uang yang diukur melalui besaran pendapatan dari sektor wisata lokal. Hal ini membutuhkan kinerja kolaborasi yang disebut dengan model triple helix secara sederhana, yaitu model untuk pengembangan industri kreatif, yang mengaktifkan peran dan fungsi (1) intelektual /akademisi /universitas; (2) bisnis /swasta yang di dalamnya termasuk para pelaku industri kreatif; dan (3) pemerintah baik pusat maupun daerah. Maka hasil analisis dari data tersebut, secara umum jelas sekali upayauntuk mempertemukan ketiga pihak tersebut belum dilakukan secara optimal (Bahren 2014, hlm. 152).

Edy Sedyawati mengatakan bahwa Industri pariwisata budaya sebenarnya memberikan banyak keuntungan, tidak hanya keuntungan ekonomi. Akan tetapi tumbuhnya industri budaya juga turut menjaga eksistensi dari budaya itu sendiri. Peranan industri budaya adalah dalam "mendemokratiskan" peluang halayak luas untuk memilih dan menikmati ungkapan-ungkapan budaya dari berbagai sumber, itu semua di samping peran ekonominya (2014, hlm. 191). 
Dampak lainnya berupa pola hidup masyarakat. Wisatawan dapat meningkatkan pendapatan penduduk, yang dapat merangsang tumbuhnya pola hidup yang bersifat konsumtif (Heru Pramono 1993, hlm. 91). Pola hidup konsumtif mendorong masyarakat pelan-pelan menjauh dari tradisi lama. Hal ini setara dengan kajian yang dilakukan oleh Spillane bahwa pola hidup konsumtif dapat menimbulkan rasa tidak puas terhadap gaya hidup tradisional mereka, dan merangsang keinginan untuk berpola hidup seperti para wisatawan yang berkunjung ke daerahnya (1987, hlm. 54).

\section{PENUTUP}

Atraksi Seni Pertunjukan Talawengkar merupakan permainan anak-anak Desa Sitiwinangun yang dikemas ke dalam sebuah bentuk seni pertunjukan yang terinsiprasi dari masyarakat yang berprofesi sebagai pengrajin gerabah di daerah sitiwinangun.

Tujuan dibuatnya Atraksi Seni Pertunjukan Talawengkar adalah untuk memberi sebuah persembahan yang berbentuk pertunjukan tari khas daerah Desa Sitiwinangun sebagai desa wisata. Atraksi Seni Pertunjukan Talawengkar adalah sebuah ekosplorasi baru dari gerabah yang sudah ditekuni oleh masyarakat setempat, sehingga adanya perkembangan kesenian baru di desa tersebut. Hal ini diharapkan dapat membuat wisatawan yang berkunjung memiliki kesan yang baik mengenai Desa Wisata Sitiwinangun dan dapat menarik wisatawan baru untuk berkunjung.
Meningkatnya kunjungan wisatawan nantinya juga akan berpengaruh langsung terhadap pendapatan desa yang berdampak langsung terhadap kesejahteraan penduduk Desa Sitiwinangun. Pertunjukan seni Talawengkar ini diharapkan masyarakat desa Sitiwinangun memiliki seni budaya lokal di bidang tari selain seni gerabah. Dengan demikian, dapat meningkatkan nilai yang bisa bertujuan untuk pengembangan nilai ekonomis.

Atraksi Seni Talawengkar juga diharapkan dapat memancing kreativitas penduduk Desa Sitiwinangun dan dapat mengeksplorasikan diri bukan hanya di bidang seni rupa gerabah, tapi juga di bidang seni pertunjukan. Sebagai sebuah sajian mengidentitas Talawengkar dapat menjadi objek daya tari wisata, memperkaya sajian seni budaya Desa Sitiwinangun Kabupaten Cirebon.

\section{Daftar Pustaka}

Abdillah, S. (2002). Politik Identitas Etnis: Pergulatan Tanda Tanpa Identitas. Magelang: Indonesiatera

Addien. (2010). Praktik Pembuatan Tanah Liat. Jakarta: Tran Mandiri Abadi.

Afandi, A, dkk, (2013). Participatory Action Reseacrh (PAR). IAIN Sunan Ampel Surabaya: LPPM.

Irianto, Agus Maladi. (2009). Media dan Multikulturalisme" dalam Yogyakarta dan Identitas Keindonesiaan (Editor: Sri Rahayu Budiarti dan Muslimin A.R. Effendy). Jakarta: Departemen 
Kebudayaan dan Pariwisata Republik Indonesia, 2009.

Putra, Agus M.(2008). Identitas \& Komodifikasi Budaya dalam Pariwisata Budaya Bali, Jurnal Analisis Pariwisata., Vol. 8, No. 2, 2008, h. 7-16.

Bahren, Hidayat. Herry Nur, Sudarmoko, Setyaka, V. (2014). Idustri Kreatif Berbasis Potensi Seni dan Sosial Budaya di Sumatra Barat, dalam Jurnal Ekspresi Seni, Vol. 16, No. 1, Juni 2014. Halaman 133-155

Afrianto, Damar Tri. (2020). Strategi Seni Pertunjukan Dengan Segmentasi Pariwisata (Kajian Pertunjukan Tallu Cappa' Di Wisata Pulau CambaCambang Pangkep" dalam Pusaka Journal of Tourism, Hospitality, Travel and Busines Event Volume 2, No.2 (2020) halaman 119-126

Arianti, Desi. (2016). Sektor Pariwisata Terhadap Perekonomian dan Keruangan Kota Bukittinggi (Pendekatan Analisis Input Output) dalam Jurnal Pembangunan Wilayah dan Kota. Biro Penerbit Planologi Undip. Desember 2016 Volume 12 (4): $347-360$

Susanto, Eko. (2017). Budaya Kreatif Dalam Konsep dan Pengembangan dalam JOMSIGN: Journal of Multicultural Studies in Guidance and Counseling Volume 1, No. 2, September 2017: Page 191-200

Hawkins, Alma M. (1991). Moving From Within: A New Method for Dance Making. Diterjemahkan oleh. I. Wayan Dibia. 2003. Bergerak Menurut Hati. Jakarta: Ford Fondation dan MSPI.

Pramono, Heru. (1993). Dampak Pembangunan Pariwisata Terhadap Ekonomi, Sosial, dan Budaya, dalam Cakrawala Pendidikan Nomor 1, Tahun XII, Februari 1993. Hal 83-93

Herdiani, Een. (2013).Tari Batik Sekar Galuh Pemberdayaan Masyarakat Paseban melalui Aktivitas Seni Budaya Lokal. Panggung, 23 (2), 212-222
Darmada, I Made. (2016). Studi Etnografi pada Budaya Lokal sebagai Pengembangan Kretivias dalam Konteks Industri Kreatif, dalam Seminar Nasional Riset Inovatif (SENARI) KE-4 Tahun 2016 ISBN 978-602-6428-04-2

Murgiyanto, Sal. (2016). Pertunjukan Budaya dan Akal Sehat. Jakarta: Fakultas Seni Pertunjukan - Institut Kesenian Jakarta

Piirto, J. (2011). Creativity for 21 st century skills: how to embed creativity into the curriculum. Ohio: Sense Publishers.

R.M Soedarsono. (1999). Seni Pertunjukan Indonesia dan Pariwisata. Bandung: Masyarakat Seni Pertunjukan Indonesia Rachmawati, Putri. \& Nanik Sri Prihartini. (2019). Inovasi Dolalak Lentera Jawa II Karya Melania Sinaring Putri. Panggung, 29 (4), 314-327

Sedyawati, E. 2014. Kebudayaan di Nusantara. Depok: Komunitas Bambu)Spillane, J.J. (1987). Ekonomi Pariwisata, Sejarah dan Prospeknya. Yogyakarta: Penerbit Kanisius.

Rustiyanti, Sri. (2019). Metode 'TaTuPa' Tabuh Tubuh dusi sebagai Musik Internal Visualisasi Koreografi NeoRandai. Resital, 20 (3), 161-175. 